\title{
International Tourists Interest in Street Vendors Souvenirs: A Descriptive Study
}

\author{
David Yoon Kin Tong ${ }^{1}$ \\ ${ }^{1}$ Faculty of Business, Multimedia University, 75450 Melaka, Malaysia
}

\begin{abstract}
The aim of this study is to analyse international tourists' interests on street vendors souvenirs sold in Melaka UNESCO sites. Their interests are then matched with the actual souvenirs sold by the vendors. Selling the wrong types of souvenirs creates a misfit between buyers and sellers and will neither benefit the tourists nor the vendors. The study was implemented in two phases. In the first phase, using judgmental sampling the survey questionnaires was distributed to international tourists walking around Christ Church and A Formosa. Of the 181 data collected, only 127 tourists expressed that they were interested in street vendors' souvenirs. This cohort of tourists and their interests were analysed using SPSS. In the second phase, using structural observations, the researcher used smart phone digital camera to capture pictures of street vendor's stores items. The photographs were uploaded in computer and the details of the items sold were zoomed in for analysis. The latter was then compared with international tourists' interests. The findings indicated that only two categories of souvenirs fulfilled the tourists' interests. This implies that the vendors have room for enhancement to include different categories of souvenirs to capture the tourists' attention.
\end{abstract}

\section{Introduction}

In 2011, Malaysia was ranked 9th as the most popular tourist destinations in the world and 3rd in Asia after China and Turkey. This achievement was made possible when UNESCO announced Melaka as a World Heritage City in July 7, 2008. With the proclamation by the government that 2014 is the 'Visit Malaysia' year, more tourists are expected to visit the country. In conjunction with this declaration and the Melaka state government's vision of 'Visiting Malacca means visiting Malaysia' past tourism records from 1999 to 2012 indicated that Melaka had 85.2 million tourists, comprising 75.7\% domestic tourists and $24.3 \%$ international tourists. In 2012, the tourism statistics showed an increase of $12.9 \%$, totalling 3.7 million in one year [1]. Tapping on the previous records, there was 3:1 ratio of domestic and international tourists in Melaka and reflecting on the income brought to tourism industry, it provides substantial income that spread across the product and service sectors.

Focusing on sale of souvenirs in the tourism industry, we revealed most souvenirs are sold in permanent outlets. For examples, the specialty store, departmental shop, merchandise retailers, dutyfree shops, gift shops, and other retailers [2]. Contrasting these outlets are street vendor stores. Street vendors are mobile and can position their stores at the vicinity or close to the tourist sites. Previous studies on souvenir items sold by fixed retail stores are well-investigated [2-3]. Currently, there is a dearth of study on vendor souvenirs sale [4-5] and we are uncertain on the demand of souvenirs by international tourists. The demand of the souvenirs is the combined result of attractions, prices, and 
quality to tourists. The key issue here is whether the local street vendors can satisfy the specific requirements of the tourists [6]. Based on this inquiry we raised two research questions for this exploratory study: 1) What types of souvenirs international tourists are looking for from the street vendor stores? 2) According to international tourists' interests, are street vendors selling the right souvenir items to them?

To answer the research questions, this study was organised in two phases. In the first phase, primary data was collected from international tourists. In the second phase, structural observation on the street vendors' stores was carried out. Photographs were taken on the displayed items in the stores. The photographs details were analysed and inferred. The outcome of this study will provide an insightful of souvenirs product purchase-selling fit. Understanding this fit will improve the revenue of these low income group traders. Finally, the study is briefly concluded.

\section{International tourists in Melaka}

\subsection{International tourists' demographic profile}

To identify international tourists' interests on street vendor souvenirs, a judgmental sampling was deployed. Judgmental sampling permits the researcher to differentiate domestic tourists from international tourists [7]. The survey questions were distributed by research assistants (RA) to international tourists that wondered around Christ Church and A Formosa.

A total of 181 valid data were collected within one month on January 2014. Of them, 127 $(70.17 \%)$ tourists expressed their interest in purchasing street vendors' souvenirs while other tourists $54(29.83 \%)$ were keen to shop in specialty or departmental stores. The latter group was excluded in the analysis. The types of souvenirs they expected from the street vendors were categorised into five product classes with references to Wilkins' study [8]. The findings indicated that $63(49.6 \%)$ of the tourists were interested in the category of photographs, paintings, postcard category; $32(25.2 \%)$ expressed they were keen on caps, hats, clothing category; 35 (27.6\%) indicated they were keen on Melaka small accessories; 49 (38.6\%) said that they would purchase the carving, jewellery, glassware, antiques category. Lastly, few were interested in the local specialty dry food products (see Table 1).

\begin{tabular}{|c|c|c|c|c|c|}
\hline \multicolumn{6}{|c|}{ Descriptive statistics results } \\
\hline \multirow[t]{2}{*}{ Gender } & & & Marital status & & \\
\hline & Frequency & $\%$ & & Frequency & $\%$ \\
\hline Male & 93 & 51.4 & Married & 78 & 43.1 \\
\hline \multirow[t]{2}{*}{ Female } & 88 & 48.6 & Single & 93 & 51.4 \\
\hline & & & Separated & 4 & 2.2 \\
\hline \multicolumn{3}{|c|}{ Is this your first visit to Melaka? } & Widowed & 1 & 0.6 \\
\hline Yes & 163 & 90.1 & Divorced & 5 & 2.8 \\
\hline No & 18 & 9.9 & & & \\
\hline \multicolumn{3}{|c|}{ Purpose of visit } & \multicolumn{3}{|c|}{$\begin{array}{l}\text { Tourists' Nationality by Countries by } \\
\text { Continents }\end{array}$} \\
\hline Pleasure & 145 & 80.1 & Europe & 134 & 74.0 \\
\hline Relaxation & 14 & 7.7 & Asia/Middle East & $10 / 3$ & $\begin{array}{c}5 . \\
5 / 1.7\end{array}$ \\
\hline Visiting & 7 & 3.9 & Oceania & 22 & 12.2 \\
\hline Business & 4 & 2.2 & North America & 11 & 6.0 \\
\hline Others & 11 & 6.1 & South America & 1 & 0.6 \\
\hline \multicolumn{6}{|l|}{ Age group } \\
\hline $20-30$ & 89 & 49.2 & & & \\
\hline
\end{tabular}




\begin{tabular}{|c|c|c|c|c|c|}
\hline $31-40$ & 51 & 28.2 & & & \\
\hline $41-50$ & 15 & 8.3 & & & \\
\hline Above 50 & 26 & 14.4 & & & \\
\hline Employment & & & $\begin{array}{l}\text { Preferred shop for } \\
\text { souvenir }\end{array}$ & & \\
\hline Employed & 113 & 62.4 & Street vendor & 127 & 70.2 \\
\hline Unemployed & 40 & 22.1 & Specialty & 40 & 22.1 \\
\hline $\begin{array}{l}\text { Self- } \\
\text { employed }\end{array}$ & 14 & 7.7 & Departmental shop & 6 & 3.3 \\
\hline Retired & 14 & 7.7 & Others & 8 & 4.4 \\
\hline
\end{tabular}

\subsection{International tourists' interest in street vendors' souvenirs - Primary data}

When asked about the main purpose of souvenirs purchase from the international tourists, 99 (78\%) of them stated that they purchased it for gift giving, and $88(69.3 \%)$ mentioned they would buy it for their own. Probing on their interests on the souvenirs, they preferred locally made souvenirs (Mean $=$ $4.32 ; \mathrm{SD}=0.95)$ and it should of reasonable quality $($ Mean $=4.09 ; \mathrm{SD}=0.93)$. Next, what would arouse them was 'value for money' (Mean $=3.82 ; \mathrm{SD}=0.89$ ). Lastly, souvenirs should be attractive $($ Mean $=3.61 ; \mathrm{SD}=0.81)($ see Table 2$)$.

Table 2. International Tourists Interest in Street Vendors' Souvenirs

\begin{tabular}{|c|c|c|c|c|c|}
\hline \multicolumn{3}{|c|}{ Types of souvenirs to purchase } & \multicolumn{3}{|c|}{$\begin{array}{l}\text { Purpose of purchase of souvenirs } \\
\text { purchase }\end{array}$} \\
\hline & No $(\%)$ & Yes $(\%)$ & & No $(\%)$ & Yes $(\%)$ \\
\hline $\begin{array}{l}\text { Photos, paintings, } \\
\text { postcard }\end{array}$ & $64(50.4)$ & $63(49.6)$ & Gift giving & $28(22)$ & $99(78)$ \\
\hline Caps, hats, clothing & $95(74.8)$ & $32(25.2)$ & Own use & $39(30.7)$ & $88(69.3)$ \\
\hline Melaka small accessories & $92(72.4)$ & $35(27.6)$ & $\begin{array}{l}\text { Assisting } \\
\text { others }\end{array}$ & $126(99.2)$ & $1(0.8)$ \\
\hline $\begin{array}{l}\text { Carving, jewellery, } \\
\text { glassware, antiques }\end{array}$ & $78(61.4)$ & $49(38.6)$ & Conscious & $117(92.1)$ & $10(7.9)$ \\
\hline $\begin{array}{l}\text { Local specialty dry food } \\
\text { products }\end{array}$ & $92(72.4)$ & $35(27.6)$ & Resale & $127(100)$ & 0 \\
\hline Others & $119(93.7)$ & $8(6.3)$ & $\begin{array}{l}\text { Other } \\
\text { purpose }\end{array}$ & $123(96.9)$ & $4(3.1)$ \\
\hline \multicolumn{4}{|l|}{ Tourists interest } & Mean & SD \\
\hline \multicolumn{4}{|c|}{ Locally made souvenirs interest me. } & 4.32 & 0.95 \\
\hline \multicolumn{4}{|c|}{ Street vendors' souvenirs with reasonable quality interest me } & 4.09 & 0.93 \\
\hline \multicolumn{4}{|c|}{$\begin{array}{l}\text { Street vendors' souvenirs that are reasonably priced interest } \\
\text { me. }\end{array}$} & 3.37 & 0.92 \\
\hline \multicolumn{4}{|c|}{$\begin{array}{l}\text { Street vendor's souvenirs that are of value for money interest } \\
\text { me. }\end{array}$} & 3.82 & 0.89 \\
\hline \multicolumn{4}{|c|}{$\begin{array}{l}\text { Street vendors selling souvenirs at a high pedestrian area } \\
\text { interest me. }\end{array}$} & 3.44 & 0.97 \\
\hline \multicolumn{4}{|c|}{$\begin{array}{l}\text { Street vendors selling souvenirs in or near tourists' area } \\
\text { interest me. }\end{array}$} & 3.31 & 0.93 \\
\hline \multicolumn{4}{|c|}{ Street vendors' stores assortment souvenirs interest me. } & 3.39 & 0.86 \\
\hline \multicolumn{4}{|c|}{ Street vendors' stores attractive souvenirs interest me. } & 3.61 & 0.84 \\
\hline
\end{tabular}




\section{Observation on street vendor operations}

In the second phase, structural observation was used for the study. This observation is a unique information gathering technique by observing participant, event or situation. Structured observation means the observer has planned and streamlined what to observe. Observation can be either participant observer or non-participant observer. Participant observer involves some intervention or process in the event, whereas non-participant observer simply observes without being bias [9]. In this study, the non-participant observation was adopted. The observation started by walking around on early February 2014 at the vicinity of the UNESCO tourist sites of Christ Church, St. Paul's Church and A Formosa. Using Nokia Lumia 1020 with 41 Megapixels camera photographs were taken on the displayed items of vendor stores. The digital pictures allow the researcher to zoom in for analysis of the items sold. The details were studied and inferred.

\subsection{Souvenir product origin}

Close scrutiny of the pictures taken on a street vendor stores items, we identified some items were locally made and some were imported goods. Figure 1(a)shows the souvenir products were made in Malaysia. The souvenirs consisted of curios such as key chains, Malay kris, the Twin Towers bells, magnets, and others. In Figure 1(b), the imported items were the rubber snakes, harmonica, plastic binoculars, catapult, whistle, etc. The origins of the products were concurred by observing the items' tags. Imported items were mainly made in China.

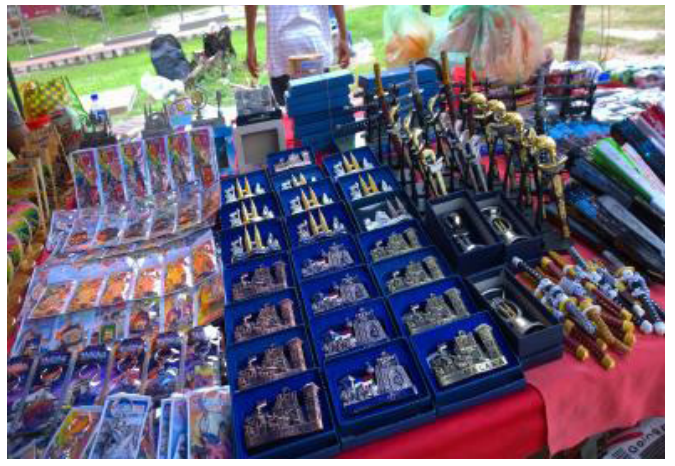

(a) Locally-made souvenirs

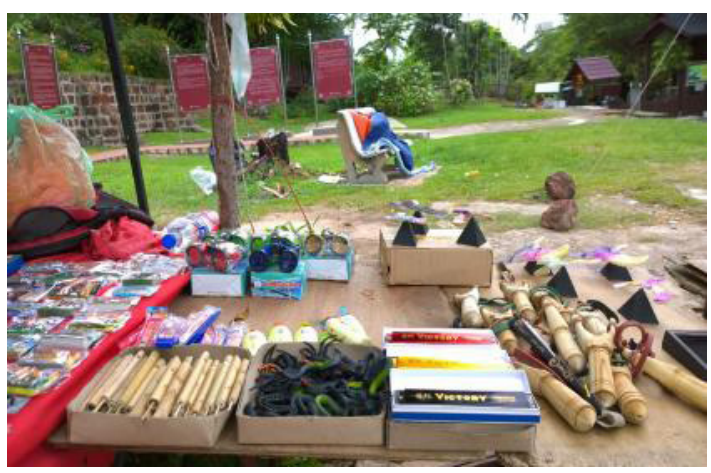

(b) Imported souvenirs

Figure 1. Souvenir Product Origin

\subsection{Souvenir Price, Quality, Value, Assortment and Attractiveness}

Based on the souvenirs' price tags, most of the souvenirs sold by the vendors were of reasonable prices. For example, in Figure 2(a), the T-shirts were sold at RM 20.00 [10]. For some vendors, the items could be bargained for lower prices. However, on the perceptions of whether the souvenirs are value for money, we found some souvenirs prices did not match its quality. They were flimsy and made of inferior materials. In Figure 2(b), it shows the name tags were made of inferior plastic quality affecting its value for money. On matching the tourists' expectations of souvenirs assortment and attractiveness, Figure 2(c) shows there were sufficient assortments but they were of different product line. For example, a vendor store has mixture of bracelets, key chains, wooden cars, and bikes. As regards souvenirs attractiveness, the miniature ships, cars, and bikes have little appeal to tourists. 
4ICTR

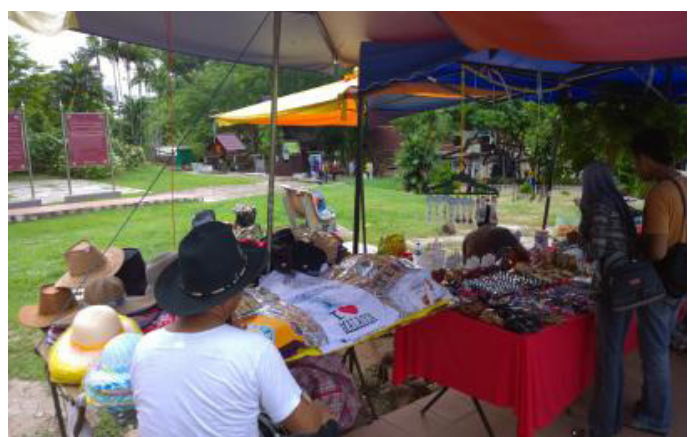

(a) Value of souvenirs

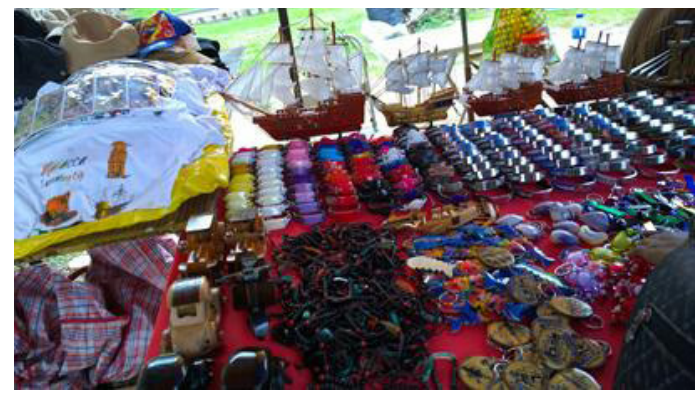

(c) Assortment and attractiveness of souvenirs

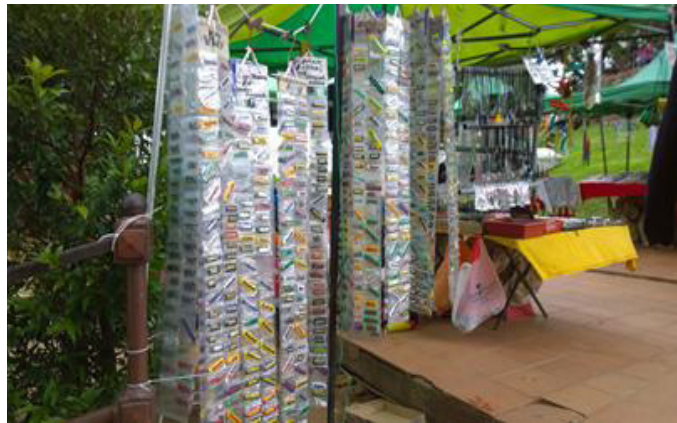

(b) Quality of souvenirs

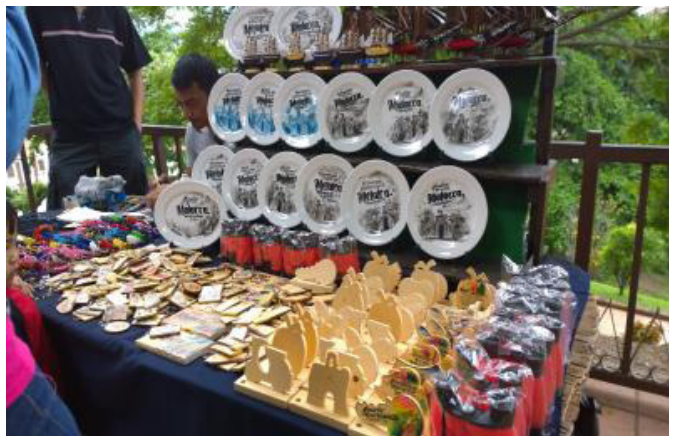

(d) Melaka small accessories

Figure 2. Souvenir Price, Quality, and Value

\subsection{Street Vendor Location}

In Figure 3, the pictures show three main locations of the street vendors at St. Paul's Church. At the entrance from A Formosa, there were three stores. At mid stairs climb to St. Paul's Church, there were four stores. Surrounding St. Paul's Church, there were three stores and around the Church, there were at least six souvenir stores. These stores set up met the expectation of the tourists that it should be at high pedestrian area or near tourists' sites (see Figure 3).

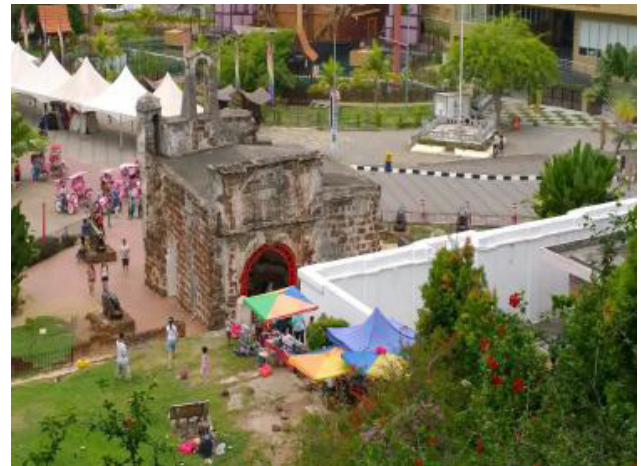

(a) Vendor stores location next to A Formosa

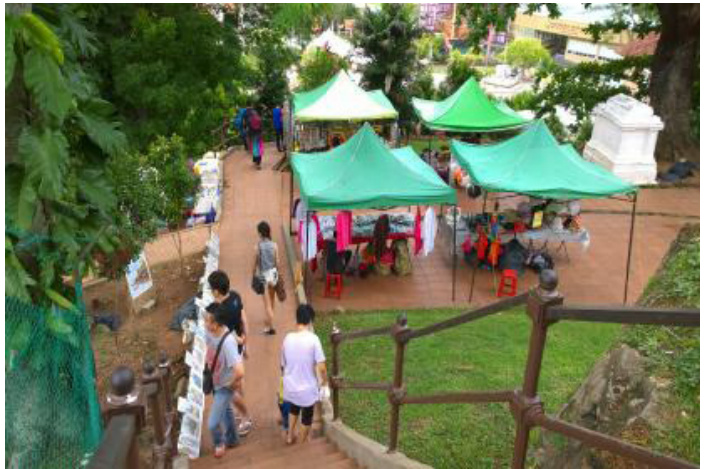

(b) Vendor stores at mid stairs to St Paul's Church 


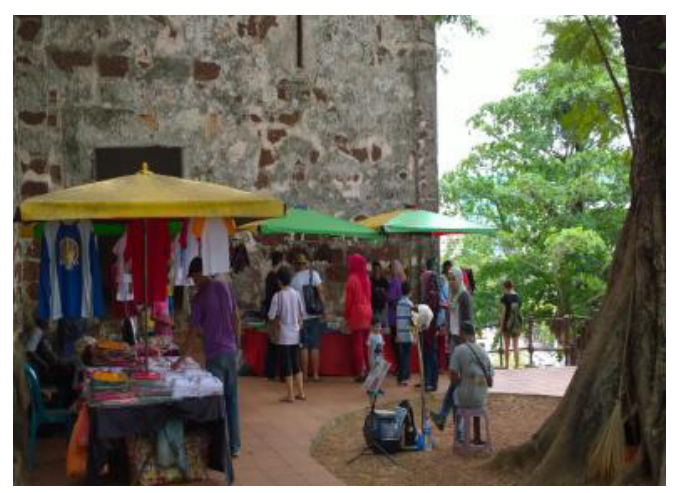

(c) Vendor stores surrounding St. Paul's

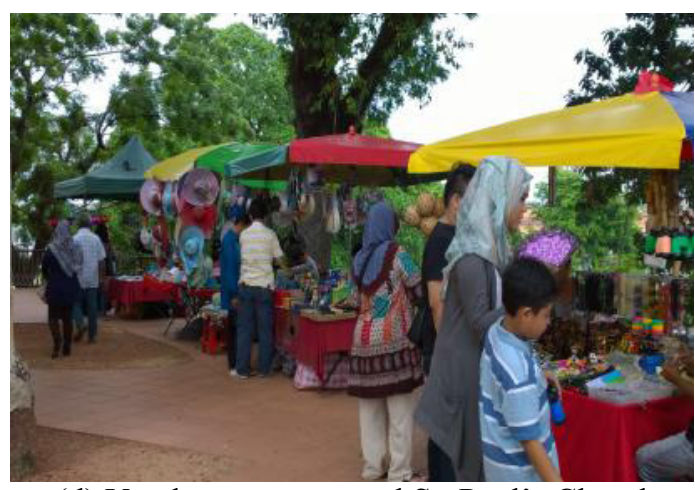

(d) Vendor stores around St. Paul's Church

Figure 3. Street Vendor Location

\subsection{Types of Souvenirs}

Lastly, we examined the types of souvenir categories that match the international tourists' interest. In the category of photograph, painting, and postcard, we found no vendor was selling those items, except three local artists were promoting their paintings on the floor. Nevertheless, for the category of caps, hats, and clothing, these items were available. As for Melaka small accessories category, Exhibit 2 P4 shows a local vendor was selling some Melaka wooden key chains, porcelain plates, cutty sark, and others. For the carving, jewellery, glassware, antiques and the local specialty dry food products categories, there was no vendor selling these items. Overall, we found similar items were sold by few vendors.

\section{Discussion and Conclusion}

In most developing countries, street vendors selling souvenirs are aplenty especially in famous tourists' sites. Whatsoever, these front line merchants play significant role in tourism industry by promoting sale of souvenirs to tourists.

The international tourists are eyeing for quality and authentic locally made souvenir products. While some souvenirs are locally made, its quality remains elusive. The vendors should consider selling items of reasonable quality to attract the tourists. Quality products attract and satisfy buyers and results in profitability [11]. In price expectation, souvenirs sold in high concentration of vendors remain competitive. Tourists delighted in bargaining will enjoy imploring for discounted price from the vendors. The lack of carving, jewellery, glassware, antiques and the local specialty dry food products categories imply that vendors should consider including these product class or category. The photograph, painting, and postcard, the pictures product class was unrepresented suggesting those local artists could display their artworks like the street vendors. These artworks should be displayed at certain height to attract the attention of buyers [12]. Vendors should also consider selling souvenirs of same product lines with real assortments; cooperate to lower the levels of duplication as it affects the value to sale [13]. Finally, the location of the stores set up met the tourists' expectations.

Street vending creates employment and income to this group of traders. Analysing their goods sold and tourists' demand contributes to the knowledge and understanding of souvenir products purchase-selling fit or misfit. However, observations on the vendors' items implied some misfit and stiff competition among another with similar items displayed for sales. Since there is a demand for locally-made souvenirs, the local craftsman can contribute to provide unique products for sale. Additionally, there are room for enhancement for vendors to sell other categories of products that are in demand by international tourists. If these items are sellable it could contribute substantially to vendors' income and local tourism sector's revenue. 


\section{References}

1. Asmaliana.com tourism blog, Melaka at a glance, (n.d.), http://asmaliana.com/blog/2013/03/27/melaka-in-a-glance/ (accessed: June 23 2014).

2. K.S. Kristen, P.E. Horridge, 2004, A Structural Model for Souvenir Consumption, Travel Activities, and Tourist Demographics, J. Travel Research, 42, 4, 372-80 (2004)

3. D. Thang, B. Tan, Linking consumer perception to preference of retail stores: an empirical assessment of the multi-attributes of store image, Journal of Retailing and Consumer Services, $\mathbf{1 0}$, 193-200 (2003)

4. D.J. Timothy, G. Wall, Selling to tourists: Indonesian street vendors, Annals of Tourism Research, 24, 2, 322-340 (1997)

5. K.S. Kristen, D.J. Timothy, Souvenirs: Icons of meaning, commercialization and commoditization, Tourism Manage., 33, 489-499 (2012)

6. D.M. Valles, Tourism and Employment: Improving the quality of tourist product (2011), http://ec.europa.eu/enterprise/sectors/tourism/files/working_groups/finalreportc_june2001_en.pdf (accessed: August 28 2014).

7. W.L. Neuman, Social Research Methods: Qualitative and Quantitative Approaches, (6 ${ }^{\text {th }}$ Ed., Pearson International Edition, USA, 2006)

8. H. Wilkins, Souvenirs: What and why we buy, Journal of Travel Research, 50, 3, 239-247 (2011)

9. B.N. Flagg, Formative evaluation for educational technologies, (Hillsdale, NJ: Erlbaum, 1990)

10. Spohia, Haggling tips, StreetDirectory Malaysia (2014), http://www.streetdirectory.com/travel_guide/malaysia/Travellers_Guide_\&_Tips/247/haggling_t ips.php (accessed: August 28 2014).

11. P. Kotler, K.L. Keller, Marketing Management, (13 ${ }^{\text {th }}$ Ed., Pearson International Edition, Pearson Prentice Hall, 2009)

12. X. Drẽze, S.J. Hoch, M.E. Purk, Shelf Management and Space Elasticity, J. of Retailing, 70, 4, 301-326 (1994)

13. R.R. Burke, 2005, Retail shoppability: A measure of the world's best stores (2005), https://kelley.iu.edu/CERR/files/shoppability.pdf (accessed: June 23 2014). 